\title{
Politics force new US rules
}

\section{Washington}

As Britain debates how to pay for its new animal welfare regulations, five years' work towards similar regulations in the United States may have been lost in another battle over economics. Under fire from the White House (see Nature 344, 804; 26 April 1990), the US Department of Agriculture (USDA) has agreed to drop proposed rules that critics claimed would cost US animal facilities nearly $\$ 900$ million and propose new less strict rules next month. But Congress and activists promise a fight before any watered-down regulations become law.

Although most of the proposed US rules were weaker than their British counterparts, the few exceptions specific standards for the exercise and well-being of dogs and non-human primates - bogged down the regulations in bureaucratic limbo while the British rules became law. As a result, USDA officials have been forced in the last month to revise the rules to stress the 'performance' of research dogs and primates, rather than the exact details of their care. Animals can be kept healthy and happy in more than one way, argued the White House and animal facility lobbyists. Demanding that facilities conform to rigid 'engineering' standards only imposes unnecessary costs, they said.

To back its claim that the proposed USDA regulations would bankrupt US research, the National Association for Biomedical Research (NABR) estimated that bringing US animal facilities up to the proposed cage and exercise standards would cost an initial $\$ 899$ million and add another $\$ 106$ million to annual costs. Almost all the expense lies in requirements that primates and dogs be given specific amounts of time and room in which to socialize and exercise, says NABR vice-president Barbara Rich.

The proposed USDA regulations went beyond current NIH guidelines for socialization and exercise by setting absoloute standards. Dogs were required to be either housed in cages large enough for them to run or to be exercised for 30 minutes a day.

Individually housed primates were to be allowed out for at least four hours of exercise and social contact a week. Many animal facilities would have been forced to enlarge their animal areas substantially and hire additional handlers to meet those standards, says Rich.

Critics of the proposed rules had also argued that, by essentially codifying the current NIH guidelines for guinea pig, rabbit and hamsters cages, USDA would have forced facilities to replace existing cages with new enclosures as little as half an inch larger. USDA intends to side step that criticism by including a 'grandfather' clause in its new rules, sources say. Animal facilities will be allowed to retain their existing cages, substituting them with larger sizes only when the old cages fall due for replacement in the normal way.

USDA officials are troubled by the new emphasis on 'performance'. Without numbers to check against, inspectors will find it difficult to verify cases of improper care, they say. And even when animal behaviour does point to negligence, inspectors will be hard pressed to defend their appraisals without quantitative evidence to back them up.

Performance-based standards "will take much more effort to enforce", says Richard Crawford, director of the USDA animal care staff. "I'm not sure how it's going to work."

Animal welfare lobbyists say that if the USDA rules finally emerge in performance-based - rather than engineeringbased - form, a lawsuit claiming distortion of congressional intent is likely. In a May letter to USDA, Congressman George Brown (Democrat, California), who heads the House of Representatives subcommittee that oversees USDA operations, warned that minimum standards are necessary to guarantee adherence. To further pressure USDA, one Brown aide says, "we could do all sorts of things, from holding oversight hearings to playing around with their funding".

G. Christopher Anderson

\section{Counting the cost of UK law}

\section{London}

BRITISH universities fear that drastic cutbacks in animal research will prove necessary if the government does not provide an extra $£ 75$ million to bring university animal houses up to the improved standards required by recent legislation. David Franks, secretary of the University of Cambridge's School of Biological Sciences, says that access to animal facilities could become a serious limiting factor for research.

A new code of practice governing the care and housing of animals was introduced last year as required under the 1986 Animals (Scientific Procedures) Act. But the cost of complying with the new code became apparent only recently, after the Universities Funding Council (UFC) asked universities to bid for funds to upgrade animal houses. The code of practice specifies standards for cage sizes, air conditioning and humidity in animal houses. Although it is not a set of mandatory requirements, the Home Office says that if facilities fall well short of standards, improvements must be made over "a not too extended" time.

The universities' estimates are unlikely to be accepted in full by UFC, which says that a panel of academics will be asked to assess the bids for funds in the coming months.

One possibility is that the UFC will suggest economies by concentrating animal houses on fewer sites at each university. But the universities argue that this has already been done, and research will suffer if extra money is not found. "We're getting to the point where we can't rationalize any more", says one senior veterinary scientist, whose own institution faces a $£ 7$ million bill. Franks says that Cambridge, which is asking for $£ 9$ million, will face "serious difficulties" if the issue is not resolved within the next year.

The current situation angers many university researchers, who point to Home Office minister David Mellor's assurance, before the 1986 Act, that the cost of changes in legislation would not fall on the universities. But the Department of Education and Science (DES) now says that this only referred to the small administrative costs linked to the new system of licensing for experimental work. A DES spokesman dismisses the universities' upgrading estimates as "speculation".

Some university administrators now say that the costs of adherence to the new standards should have been estimated when they were drafted, and the code of practice amended to give a compromise between the desirable and the affordable, similar to the current US approach (see above). Standards for air conditioning and humidity are thought by some to be too strict.

Commercial laboratories, with greater funds at their disposal, had few problems meeting the required standards. The head of the animal health division at one of Britain's largest drug companies says that his company has a constant programme of upgrading its animal facilities, so the short-term impact of the new code of practice is very slight.

A Home Office spokesman says that universities financial difficulties will not make them a special case, and enforced closure of some animal houses is a possibility if standards cannot be improved. One veterinary scientist, who is a strong supporter of the code of practice, says half of university animal houses may be below the required standard. If the majority of the British public supports the use of animals in biomedical research, he says, then "society has to be prepared to pay".

Peter Aldhous 